\title{
ADDENDUM
}

\section{The rise and fall of methanotrophy following a deepwater oil-well blowout}

\author{
M. Crespo-Medina, C. D. Meile, K. S. Hunter, A-R. Diercks, V. L. Asper, V. J. Orphan, P. L. Tavormina, L. M. Nigro, \\ J. J. Battles, J. P. Chanton, A. M. Shiller, D-J. Joung, R. M. W. Amon, A. Bracco, J. P. Montoya, T. A. Villareal, A. M. Wood \\ and S. B. Joye
}

Nature Geoscience 7, 423-427 (2014); published online 11 May 2014; corrected after print 28 April 2015.

We would like to provide a more comprehensive description of sample handling and the timing of methane oxidation rate assays.

The special circumstances of the Deepwater Horizon oil-well blowout required adaptation of standard operating procedures. As a result, methane oxidation rate assays on 248 of the 1,128 samples we took in our study were not initiated within 12-24 hours of sample collection (Supplementary Table 1), because some cruises lacked a radioisotope isolation van and samples had to be shipped to the University of Georgia for processing after the cruise ended. Specifically, on the RV Pelican, RV Walton Smith, RV Arctic Sunrise, and the RV Nancy Foster cruises, samples were stored for up to 29 days before initiation of rate assays. Sample storage times for these cruises are given in Supplementary Table 1.

To evaluate potential issues arising from storage and shipping, we measured the concentration of dissolved oxygen and nutrients on the ship and after storage, and bottles were visually inspected for gas bubbles, and visible changes (for example, turbidity, aggregations) in microbial biomass. On board the ship, samples were stored without a headspace in a gas-tight bottle in a refrigerator set at $4{ }^{\circ} \mathrm{C}$. The temperature of the refrigerator was checked at least every four hours to assure stability. We prepared samples for shipment to Athens (Georgia, USA) by placing them on a layer of Styrofoam peanuts ( $2.5 \mathrm{~cm}$ thick), which overlaid a layer of blue ice packs. Similarly, blue ice packs lined the sides of each cooler and were separated from the sample bottles by cardboard. A piece of cardboard was placed on top of the samples, and an ice pack was then placed on top of the cardboard. No warming occurred during shipment and samples remained at deep-sea temperatures $\left(3-4^{\circ} \mathrm{C}\right)$ until arrival in Athens.

Several lines of evidence show that storage did not affect our results. First, visual assessment gave no indication of changes in microbial biomass (for example, blooms) during storage: there were no cell clumps, no visible turbidity, no microbial slime, and no growth on container walls, any of which could signal cell growth or death during storage. Second, no bottles went anoxic or exhibited the levels of nutrient or oxygen drawdown that would point towards a microbial population explosion during storage and/or shipment. Third, an increase of methanotroph biomass during storage would have increased the volumetric rates of methane oxidation and decreased the substrate concentration, both of which would increase the value of $k$, the specific methane oxidation rate. Our data show no such relationship between storage time and $k$; this is particularly noteworthy for the high-activity period in late May and early June.

These observations are consistent with the current understanding of methanotrophs, which are fastidious and difficult to enrich and isolate, and tend to be inactive under stable (static) storage conditions ${ }^{1-3}$. Gulf waters, incubated in stirred bottles and monitored over time to track changes in methane concentration, have been used to estimate methane oxidation rates from the linear decrease in methane concentration over time in bottles during laboratory incubation ${ }^{1-3}$. Over periods up to 30 days, methane concentrations decreased linearly (with $r^{2}$ varying from 0.995 to 0.973 ). These observations have been replicated multiple times ${ }^{2}$, and clearly show that methanotrophy depends upon turbulence: bottles incubated under static/stable conditions showed no significant methane consumption ${ }^{2}$. This reflects the common observation that headspace-free static storage or static incubation generally reflects lower microbial growth and activity ${ }^{4-6}$.

Furthermore, methane oxidation rates determined from stored samples exhibited a similar pattern - as did the distribution of a key functional gene involved in aerobic methane oxidation, $p m o A$, measured in samples filtered and fixed on board the ship. Both rates (Fig. 1) and pmoA gene abundance (Fig. 2) increased by orders of magnitude in late May and early June and then relaxed back towards much lower values, although both remained above background values. As the molecular samples were filtered and fixed on board the ship, the $p m o A$ gene abundance data cannot reflect a storage effect. We conclude that the likelihood of a methanotroph bloom during storage of these samples is exceedingly small.

\section{References}

1. Bugna, G. C., Chanton, J. P., Young, J. E., Burnett, W. C. \& Cable, P. H. The importance of groundwater discharge to the methane budget of nearshore and continental shelf waters of the NE Gulf of Mexico. Geochim. Cosmochim. Acta 60, 4735-4746 (1996).

2. Bugna, G. C. Methane as a Tracer of Submarine Groundwater Discharge into the NE Gulf of Mexico Masters thesis, Florida State Univ. (1995).

3. Kelley, C. A. Methane oxidation potential in the water column of two diverse coastal marine sites. Biogeochemistry 65, 105-120 (2003).

4. Lidstrom, M. E. Isolation and characterization of marine methanotrophs. A. Van Leeuw. J. Microb. 54, 189-199 (1988).

5. Wartiainen, I., Hestnes, A. G., McDonald, I. R. \& Svenning, M. M. Methylobacter tundripaludum sp. nov., a methane-oxidizing bacterium from Arctic wetland soil on the Svalbard islands, Norway (78 N). Int. J. Sys. Evol. Microbiol. 56, 109-113 (2006).

6. Juergensmeyer, M. A., Nelson, E. S. \& Juergensmeyer, E. A. Shaking alone, without concurrent aeration, affects the growth characteristics of Eschericia coli. Lett. Appl. Microbiol. 45, 179-183 (2007).

\section{Additional information}

Supplementary information is available in the online version of the Addendum. 